\begin{tabular}{|l|l|l|}
\hline \multicolumn{2}{|c|}{ PublisherInfo } \\
\hline \hline PublisherName & $:$ & BioMed Central \\
\hline \hline PublisherLocation & $:$ & London \\
\hline \hline PublisherImprintName & $:$ & BioMed Central \\
\hline \hline
\end{tabular}

\title{
The ESSENCE of exon inclusion
}

\begin{tabular}{|l|l|l||}
\hline \multicolumn{2}{|c||}{ ArticleInfo } \\
\hline \hline ArticleID & $:$ & 4680 \\
\hline \hline ArticleDOI & $:$ & 10.1186 /gb-spotlight-20030117-01 \\
\hline \hline ArticleCitationID & $:$ & spotlight-20030117-01 \\
\hline \hline ArticleSequenceNumber & $:$ & 32 \\
\hline \hline ArticleCategory & $:$ & Research news \\
\hline ArticleFirstPage & $:$ & 1 \\
\hline \hline ArticleLastPage & $:$ & 2 \\
\hline \hline & & RegistrationDate : 2003-1-17 \\
\hline ArticleHistory & $:$ & OnlineDate \\
\hline \hline ArticleCopyright & $:$ & BioMed Central Ltd2003-17 \\
\hline \hline ArticleGrants & $:$ & \\
\hline \hline ArticleContext & $:$ & 130594411 \\
\hline \hline
\end{tabular}




\section{Jonathan B Weitzman}

Email: jonathanweitzman@hotmail.com

Many human genetic diseases are due to point mutations that cause aberrant splicing. These may affect splice-site sequences directly, or may disrupt regulatory elements such as exonic splicing enhancers (ESE). ESEs are binding sites for serine/arginine-rich (SR) splicing factor proteins. In an Advanced Online Publication in Nature Structural Biology, Luca Cartegni and Adrian Krainer, at Cold Spring Harbor Laboratory, New York, US, describe the design of synthetic proteins that can promote specific exon inclusion (Nature Structural Biology, DOI:10.1038/nsb887, 13 January 2003). Cartegni and Krainer fused the minimal RS domain from SR proteins with an antisense moiety for targeting to specific exons. They demonstrated the efficiency of this technique using transcripts from the BRCAI and $S M N 2$ genes. This approach (which they dubbed ESSENCE - exon-specific splicing enhancement by small chimeric effectors) may be used to designed therapeutic compounds to include exons that have been skipped, for example due to genome mutations in splice acceptors.

\section{References}

1. Listening to silence and understanding nonsense: exonic mutations that affect splicing.

2. Nature Structural Biology, [http://www.nature.com/naturestructuralbiology]

3. Cold Spring Harbor Laboratory, [http://www.cshl.edu]

This PDF file was created after publication. 